\title{
HUMOR IN JULIO RAMÓN RIBEYRO'S SHORT STORIES: CONSEQUENCE OR CAUSE OF THE FANTASTIC?
}

\author{
ERWIN SNAUWAERT \\ KU Leuven Campus Brussel \\ erwin.snauwaert@kuleuven.be
}

Recibido: 28-05-2018

Aceptado: 28-05-2018

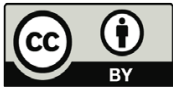

\section{ABSTRACT}

Although fantastic narrative and humor increasingly go together - both arise from an incongruity that affects objective reality and pragmatics, respectively-, this combination is not always unambiguous. More specifically, the humorous effect depends on the modality in which the fantastic takes place: in 'the fantastic of perception', humor is only a consequence of the clash between the uncanny and everyday life, while in 'the fantastic of language' it is incorporated into the enunciation and causes the very fantastic effect. Both modalities are illustrated in some relevant short stories of Julio Ramón Ribeyro. The first occurs in Doblaje, La insignia and La botella de chicha, where the hero's confrontation with a disquieting event leads to mere situational humor. The second is realized by a defective narration in Escena de caza and El carrusel or by a suggestive focalization in Sobre las olas and Scorpio, which kindle an absurd humor that triggers the fantastic.

KEY WoRDS: Fantastic of perception, fantastic of language, humor, narration and focalization, Julio Ramón Ribeyro.

\section{RESUMEN}

Aunque la narrativa fantástica y el humor cada vez más se compenetran —ambos se basan en una incongruencia que afecta respectivamente a la realidad objetiva y a la pragmática - esta combinación no siempre es unívoca. Más específicamente, el efecto humorístico depende de las modalidades según las cuales opera lo fantástico: en 'lo fantástico de percepción', el humor es mera consecuencia de la colisión entre lo insólito y la vida cotidiana, mientras en 'lo fantástico de lenguaje' participa en la enuncia- 
ción, por lo que causa el propio efecto fantástico. Ambas modalidades se ejemplifican en unos cuentos de Julio Ramón Ribeyro. La primera se ilustra en Doblaje, La insignia y La botella de chicha, relatos en los que la confrontación del héroe con un acontecimiento descomunal origina un humor puramente situacional. La segunda es realizada por una narración defectuosa en Escena de caza y El carrusel o por unas focalizaciones sugestivas en Sobre las olas y Scorpio, unos procedimientos que ponen en marcha un humor absurdo que lleva a lo fantástico.

Palabras clave: fantástico de percepción, fantástico de lenguaje, humor, narración y focalización, Julio Ramón Ribeyro.

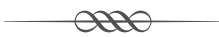

\section{INTRODUCTION}

In his study of the modernization process in Peruvian fantastic narrative, Elton Honores states that very often the fantastic effect is expressed by means of parody and humor (2010: 209). Bearing in mind the fact that humor is only one of many phenomena to associate with the fantastic, we will, nonetheless, give it our undivided attention. More specifically, we will examine the causality between these concepts: can humor be considered as an aftereffect of the fantastic, or is it, on the contrary, its raison d'être? Before coming to this, it is necessary, first, to describe how humor and the fantastic share some principles of transgression and narrative structure and, second, to explain how both terms increasingly intertwine under the influence of postmodernism. Nevertheless, in spite of these affinities, their relationship does not always come across as univocal. Therefore, this contribution links humor to the 'fantastic of perception' and the 'fantastic of language', two modalities that are indispensable to a good understanding of the corresponding narrative that has been written in the second half of the twentieth century. In order to clarify their mechanisms, we will examine both modalities departing from a set of Julio Ramón Ribeyro's (Lima, 1929-1994) fantastic short stories. Although these tales only constitute a small part of the author's overall production (Vidal, 1975: 77), which is collected in Cuentos completos (1994), ${ }^{1}$ they are very relevant to our issue as they frequently combine fantastic effects and humor.

1 These short stories have also been collected in La palabra del mudo. The first edition of 1974 included the collections Los gallinazos sin plumas (1955), Cuentos de circunstancias (1958), Las botellas y los hombres 


\section{AfFinities BETWEEN HUMOR AND THE FANTASTIC: TRANSGRESSION}

AND NARRATIVE STRUCTURE

In his famous definition, Todorov states that the fantastic effect is triggered by «the vacillation» («l'hésitation») between «the strange» («l'étrange») and «the marvelous» («le merveilleux»), two extreme concepts by means of which characters and readers classify facts that exceed their experiences of reality respectively as either illusive or as superhuman (1970: 29). Since the narrator presents these irrational aspects as problematic and disturbing, the «fantastic» differs from «magic realism», in which the supernatural elements are considered to be integrated into a conventional perception of reality (Chanady, 1985: 23). Technically, this vacillation is derived from a process of transgression at the levels of semantics, narrative syntax, and discourse. The first deals with rhetoric procedures such as exaggeration, confusion between literal and figurative meaning, and metaphors of animals or unusual objects, whereas the second focuses on the way in which the text arranges different events in order to emphasize their uncommon nature. The third, finally, relates to the enunciation, more specifically, to the literary play with space and time, such as regressive ending, 'metalepsis', or other manipulations of narration that create a sensation of subversion and doubt, which are consubstantial of the genre (Todorov, 1970: 81-87).

Such a process of transgression is also typical of humor, a phenomenon which can be considered relevant to the understanding of «art and life» since it teaches us how the "human (...), social, collective, popular imagination works» (Bergson, 1991: 2). ${ }^{2}$ Just like the fantastic questions reality and the laws of nature by establishing hesitation between 'the strange' and 'the marvelous', humor commonly infringes the pragmatic rules of communication by creating an incongruity that prompts the reader to abandon a first erroneous interpretation in search of an unexpected meaning, as stated by Ermida.

(1964), Tres historias sublevantes (1964), Los cautivos (1972) and El próximo mes me nivelo (1972) and has been built out until 2010, incorporating the books Silvio en el Rosedal (1977), Sólo para fumadores (1987), Relatos Santacrucinos (1992) and ten supplementary tales. For the rest, the narrative of Ribeyro is also known from his novels Crónica de San Gabriel (1960), Los geniecillos dominicales (1965) and Cambio de Guardia (1976) and from his short essays Prosas apátridas (1975).

2 These quotes are a translation of the original fragment «comment la fantaisie comique ne nous renseignerait-elle pas sur les procédés de travail de l'imagination humaine (...), de l'imagination sociale, collective, populaire? Issue de la vie réelle, apparentée a l'art, comment ne nous dirait-elle pas aussi son mot sur l'art et sur la vie» (Bergson, 1991: 2). Furthermore, Bergson puts forward as main characteristics of humor its human origin -no animal is seen as comical unless it is associated with human nature- and its mechanical and unexpected functioning, which relates to the concepts of incongruity and transgression we will refer to. 
The idea that humor results from the combination of dissimilar elements and feeds on the consequent surprising effect is an established one. From this perspective, contrast and surprise equal humor. When we find something funny, it is because the sudden perception of an incongruity makes us drop our initially wrong interpretation, and, as if in a game, search for a surprising meaning we had not anticipated (Ermida, 2008: 25).

Moreover, Ermida emphasizes the classic distinction between «a situational or physical humor» and «a linguistic one», which in a «longer humorous discourse (...) may depend on the way verbal expression is manoeuvred and processed» and «thrives on all levels of linguistic analysis: from sound to morpheme, from word to sentence, from text to context» (2008: 41).

According to Vandaele, these specific linguistic processes may constitute a structural meeting point between «humor» and «narrative», two concepts that are intrinsically different: «while narrative contains minimally two layers of intentionality (oriented to the action and its presentation), humor can but need not involve those two layers; inversely, while humor always requires subjects to perceive incongruity and feel superiority, narrative is not defined by incongruity and superiority, although it can produce them» (2012: 59). Hence, «humor is narrative when it creates and / or exploits incongruity and superiority relations among the participants of narrative texts» (Vandaele, 2010: 732) and can only be explained by means of a «discursive, intentionalist (action- and participant-centered) analysis» (Vandaele, 2012: 86). These observations corroborate the insights of Attardo, who also relates humor to the existence of «a text (...) told by a narrator (...) with realistic illusion» and allowing that «any character in a narrative (...) may initiate another narrative embedded in it» (2001: 80), and put forward the significance of narrative processes like narration and focalization. Actually, these modalities can pave the way for incongruity - and generate the corresponding superiority feelings Vandaele alludes to- by influencing the balance of powers between the narrative agents involved, which may foster the creation of humor. ${ }^{3}$

As far as the narration is concerned, the narrator can kindle humor in a metanarrative way by providing comments that undermine his own authority or the narration laws in the same way that, in a metalinguistic context, a pun actualizes some meanings that do not commonly appear in normal speech

3 At this stage, the narrative analysis of humor also fits with the General Theory of Verbal Humor (GTVH), which presents «Narrative Strategy» as one of the «Knowledge Resources» among others, like «Script Opposition», «Logical Mechanism», «Situation», «Target» and «Language» (Antonopoulou, 2002: 198). 
(Vandaele, 2010: 738). Such unexpected interpretations may arise, for instance, when the narrator withholds some information like in the following situation, reproduced by Vandaele: ${ }^{4}$ a patient asks his doctor's wife if her husband is home and is happy to hear the negative answer because this gives him the opportunity to have sex with her (2010: 748). The surprising effect is clearly linked to the narration which, by passing over in silence, and hence concealing the underlying intentions of the patient, creates the atmosphere of a medical consultation, which afterwards is countered by the man's real objective and puts the reader off his stride (2010: 749-750).

The reader can also be fooled by the aberrant focalizations of some characters that, by their specific qualifications of a certain object, set the values they stand for and determine the dominant perspective of the story (Rabatel, 2009: 79). Vandaele mentions the example of Billy Wilder's The Seven Year Itch (1955), a movie in which the spectator adopts the point of view of a man who fantasizes about an imminent date with a beautiful woman, but, when finally the doorbell rings, finds himself on the doorstep face to face with an ugly janitor (2010: 756). Although, in this case, humor is also partly situational because of the doorkeeper's inopportune visit or his ridiculous look, ${ }^{5}$ it mainly arises from the maladjusted perspective that deceives the hopes of the audience. This kind of operation exploits the contiguity between the characters and the narrators -in a similar fashion as free indirect speech (2010: 767-768) — in order to make them clash more intensively and produce the incongruity needed to bring about humor. In this respect, narrative humor connects to the fantastic not only by means of a similar process of transgression conditioned by incongruity and vacillation, but also by the fact that this transgression of commonly accepted rules is grounded in experiments with enunciation that lead to ambiguity and unsettle the reader. Such a process also shows to what extent «[E]l humor funciona como una caja de resonancia para lo fantástico. Lo humorístico exige (...) una actitud dialógica dentro de y con el texto, con lo cual obliga al lector a reconocer los referentes reformulados para así desembocar en un proceso de lectura más activo» (Alarcón, 2013: 85).

4 More specifically, Vandaele refers to the example given by Attardo (2001: 21-22), who synthesizes a joke described earlier by Raskin (1985).

5 As a matter of fact, a character can also be seen as ridiculous on its own. A shining example is Basil, the protagonist of the famous English serial Fawlty Towers, whose behavior is judged inappropriate by the spectator without any mediation of a narrator (Vandaele, 2010: 767). 


\section{The 'Fantastic of Perception' versus the 'FAntastic of Language'}

Erdal Jordan considers such a manipulation of narrative enunciation ${ }^{6}$ as evidence of the redefinition of the vacillation concept that has been imposed by postmodernism (1998: 38). By giving up the ambition of representation that was typical of realism, and to a smaller degree, of modernism, postmodernism ended up eroding one of the fundaments of fantastic literature, which, in order to stimulate hesitation, always requires a referential and veracious context (1998: 53). As they sacrifice their representative aspirations for an autonomous and self-referring language play, postmodern texts make it more difficult to locate the typical doubtfulness between 'the strange' and 'the marvelous' and compel the genre to establish it in a different way.

According to Roas, this development explains the boom of some narrative artifices, which ensure that, when narrators proceed to the representation of the impossible, their expression becomes obscure, awkward, indirect: «su expresión suele volverse oscura, torpe, indirecta» (2011: 264). In order to allude to something indefinable, narrators put into practice certain strategies of discourse such as metaphors, neologisms, oxymora, or colored adjectives. Concurrently, they manipulate the enunciation by installing a «retórica de lo indecible», a «rhetoric of the unspeakable», by means of a systematic exploitation of self-referring narration, intertextuality, and a play with 'metafiction', which are all textual strategies that lead to a crisis of the illusion of reality that mimesis postulates: «unas estrategias textuales que ponen en crisis la ilusión de realidad que postula la mimesis» (2011: 266).

These evolutions incited Rodríguez Hernández to make a distinction between a «fantastic of perception» («fantástico de percepción») and a «fantastic of language» or «of discourse» («fantástico de lenguaje»/ «fantástico del discurso») (2010: 4). In the first case, vacillation is induced essentially at a semantic level by the prototypical combination of a mimetic context and a supernatural element (2010: 3), such as the presence in daily life of futuristic machines, uncommon animals, or elements of a cybernetic post-human world. In the second, the doubt is configured in its verbal aspect starting from a peculiar arrangement of narrative tools and formal or rhetoric mechanisms (2010: 5), according to the recent evolution of the genre discussed above.

6 This tendency connects with the theory of 'unnatural narratology', which focuses explicitly on narrative structures — such as, for instance, posthumous narrators as they appear in some works by Machado de Assis, Rulfo or Bolaño-, which, in spite of their familiar aspect, are considered to be 'anti-mimetic' since they operate according to scripts that are incompatible with the laws of the physical and logical world (Alber, 2011; Alber and Fludernik, 2010). 
If we focus on Peruvian literature, which includes Julio Ramón Ribeyro's short stories, the 'fantastic of perception' fits in with what Honores calls «the transgressive aspects» («los aspectos transgresivos») that take shape in the transgression of time and place and in the figure of the double (2010: 33). The 'fantastic of language', on the other hand, has to do with formal renovation (2010: 36) and crystallizes in the influence of Kafka («la influencia de Kafka») —-through the attention paid to irrationality, the absurd organization of everyday life, or psychological intrigue - and also in a variant that is defined as «playful, aesthetically oriented or philosophical and moral», «lo fantástico lúdico, esteticista o filosófico moral» (2010: 33). In the latter category, the fantastic effect is not only realized by inventing structural artifices in narrative time and space — like dilatation (Roas, 2012: 108), a regressive ending or metalepsis - or experiments with enunciation — such as the constitution of a non-anthropomorphic or posthumous narrator that creates an uncanny atmosphere (Honores 195) — but also by means of irony and grotesque humor: «la ironía y el humor grotescos» (2010: 33). ${ }^{7}$

The fact that humor, as we have already seen, is based on a similar transgression of rules that are supposed to be generally accepted and often configures an ambiguous narration allows us to consider it, together with Honores, as a fully-fledged instrument of the fantastic in contemporary Peruvian literature (2011: 29-32). At the same time, this statement also raises the question of how humor exactly impacts upon vacillation and, more specifically, how it relates to the 'fantastic of perception' and the 'fantastic of language'. Therefore, we will analyze both variants in the seven tales of Ribeyro that combine fantastic and humor in the clearest way: Doblaje, La insignia, La botella de chicha, Escena de caza, El carrusel, Sobre las olas and Scorpio. ${ }^{8}$ Although these modalities of 'perception' and 'language' do not always appear exclusively in only one tale, we will focus on the former in the first three stories, which put

7 At this stage, Honores puts together two terms that are often separated in theoretical models since humor does not coincide with irony. The latter is more specifically seen as «a strange mode of discourse where you say something you don't actually mean and expect people to understand» (Hutcheon, 1995: 2). Nevertheless, although Hutcheon wants to preserve us from such a «conflation of irony and humor » (1995: 5), she also states that «the affective dimension of irony (its link to fear, unease, superiority, putdown, control) and its formal dimensions (juxtaposition, incompatibility) find their way into theories of humor as well» (1995: 26). Hence, we will not elaborate on the difference between these two concepts, which goes beyond of the scope of this article.

8 Joining the classifications of Rodero (2000: 89) and Honores (2010: 33), which take into account the fantastic genre in its broadest scope, 19 of Ribeyro's 97 short stories can be listed as fantastic. Although we cannot ignore the sporadic presence of a slight humorous tonality in the others — such as Ridder y el pisapapeles, in which the inexplicable reappearing of a paperweight alternates with the disenchantment experienced by the hero while interviewing his favorite writer-, the tales where, in our opinion, humor and fantastic manifestly go together are the seven incorporated in this study. 
forward some uncommon event, and on the latter in the last four, where the fantastic infringes on the narrative codes (Ortega, 1985: 140) manipulating both narration and focalization.

\section{The 'FAntAstic OF PERCEPTION': HUMOR AS A CONSEQUENCE}

As far as the 'fantastic of perception' is concerned, the short stories that most obviously link the appearance of something abnormal to a humoristic elaboration are Doblaje, La insignia and La botella de chicha. ${ }^{9}$ According to Weitzdörfer, in the first two stories, the fantastic is rooted in a «base pseudocientífica», a «pseudoscientific base» (2008: 194). At the beginning of the first one, the autodiegetic narrator declares himself inspired by an esoteric Indian theory, which postulates that every person has a double at the other end of the world.

En aquella época vivía en un pequeño hotel cerca de Charing Cross y pasaba los días pintando y leyendo libros de ocultismo. (...) mi padre estuvo muchos años en la India y trajo de las orillas del Ganges, aparte de un paludismo feroz, una colección completa de trabajos de esoterismo. En uno de estos libros leía una vez una frase que despertó mi curiosidad. (...) «Todos tenemos un doble que vive en las antípodas. Pero encontrarlo es muy difícil porque los dobles tienden siempre a efectuar el movimiento contrario» (Ribeyro, 1994: 91).

Given that it is not easy to find that double, which presupposes not only a physical but also a spiritual similarity (Ribeyro, 1994: 91), the narrator-protagonist decides to leave the painting of a Madonna that is under construction and begins an obsessive quest for his perfect doppelgänger. Realizing that such a double cannot loom up out of the bowels of the earth, «del seno de la tierra», but probably exists as a sort of antipode (1994: 92), he travels from London to Sydney. There he gives full rein to his uncommon passion for Australian goats (1994: 92) but fails to meet his alter ego and only succeeds to have a turbulent romance with Winnie, an eccentric local woman. When, after a dreadful scene of jealousy, this love comes to an end and Winnie disappears without a trace, the hero starts acting like a fool and eventually goes back to Britain. Home again, he recovers his traditional English equanimity, but is shocked by a striking detail: the painting he had left behind as a sketch

9 These three stories are incorporated in the same collection, Cuentos de circunstancias (1958). 
is now finished in a masterly way and, to top it off, displays the face of his Australian girlfriend, while a yellow butterfly, similar to those that once decorated the walls of their apartment in Sydney, is flying around it: «la madona que dejara en bosquejo estaba terminada con la destreza de un maestro y su rostro, cosa extraña, su rostro era de Winnie. (...) Alrededor revoloteaba una mariposa amarilla» (Ribeyro, 1994: 95).

Even though in this tale the funny ending is being announced by some sarcastic comments - such as the statement in the first quote, revealing that the hero's father not only brought along books from his tropical journey but also an acute swamp fever, "un paludismo feroz», or the saying that summarizes the apparent uselessness of the protagonist's travel: «Partir es una gran cosa (...) pero lo maravilloso es regresar» (1994: 95) — it mainly proceeds from the very uncanny fact. This «cosa extraña» is that, obviously, the double exists - people told the hero he forgot his umbrella at the London Mandrake Club while, in fact, he was flying over Singapore (1994: 95) — and, moreover, traveled in the opposite direction. Both the manifested existence of the double, which corroborates the speculative theory explained in the first lines of the story, and its anticipation of the protagonist's plans create the incongruity between the reader's expectations and the surprising climax and produce the humorous effect.

Another pseudoscientific mechanism can be traced in La insignia, which establishes an abnormal but perfectly understandable logic: «una lógica perfectamente comprensible dentro de lo anormal» (Weitzdörfer, 2008: 196). Out for a walk on the seafront, the hero finds a silver pin with some sibylline inscriptions, puts it into the pocket of his jacket and does not pay any more attention to it until, much later, the manager of the cleaner's where he had brought the jacket to wash discovers the little jewel. Amazed by the shining it got after having been rubbed, he pins it up and from that moment on he is accosted by different kind of people, like a bookseller who claims to be aware of his interest in the work of a mysterious author called Feifer (1994: 83) or a little man with a hatched face and the look of a liver patient who invites him surreptitiously for a cabalistic meeting which the strange badge permits him to attend (1994: 84). This assembly, which seems to stay midway between a religious sect and a cloth factory (1994: 86), tackles the most diverse issues, ranging from state affairs over childhood memories to the cultivation of beetroots (1994: 84). Moreover, at the end of the session, its chairman burdens the protagonist with the most absurd tasks: he is supposed to list all telephone numbers starting with 38, collect twelve parrots, sketch a town hall in a distant province, throw banana skins on the doorsteps of a number of carefully 
selected mansions, write an article about celestial bodies, and peep at exotic women (Ribeyro, 1994: 85). By engaging in these obscure activities, he grows estranged from his relatives who increasingly regard him as an alien. At the same time, however, he moves up in the ranks of the odd brotherhood, which grants him access to the best hotels in the world and endows him with countless privileges.

Han pasado diez años. Por mis propios méritos he sido designado presidente. Uso una toga orlada púrpura con la que aparezco en los grandes ceremoniales. (...) Tengo una renta de cinco mil dólares, casa en los balnearios, sirvientes con librea que me respetan y me temen, y hasta una mujer encantadora que viene a mí por las noches sin que yo la llame. $\mathrm{Y}$ a pesar de todo esto, ahora, como el primer día y como siempre, vivo en la más absoluta ignorancia, y si alguien me preguntara cuál es el sentido de nuestra organización, yo no sabría qué responderle (Ribeyro, 1994: 86).

The arbitrariness of his mission and its exorbitant recompense - his appointment to the post of president, his personal earnings, the beautiful woman at his service - contrast with the global setting of the tale, which, apart from that, is that of everyday life. According to Roas, this referential atmosphere contributes to the fantastic effect as it manages to convince the reader of the «truth» of the impossible, "para conseguir convencer al lector de la "verdad" del fenómeno imposible» (2011: 263). In this case, vacillation mainly proceeds from the mystery that surrounds the protagonist. This mystery is rooted in a system that operates in accordance with its rigid logic but whose relationship with reality increasingly vanishes and finally entails an absurd effect. The resulting effect underscores the incongruity that magnifies the ridiculous of the situation or hints at the ironic remarks - like the hero's allusion to his own merits, «mis propios méritos», while he ignores the reasons for his success and the objectives of the organization - and eventually leads to humor.

Also La botella de chicha, which is characterized by its «ironía y humor grotescos» (Honores, 2010: 33), can be read as a classic example of 'the fantastic of perception'. The fantastic resides in the impossible transubstantiation of a beverage: because he needs money, the hero decides to sell an exclusive chicha that has been having «the sleep of the just», «el sueño de los justos», (Ribeyro, 1994: 106) in his parent's cupboard during more than fifteen years, waiting to be uncorked on a special occasion that never arose. Therefore, he siphons it over in a small cask and, after having refilled the rest of the original bottle with vinegar, steps into the road to offer the top 
class corn wine for sale, but no barkeeper wants to buy it. Home again, the protagonist's humiliation turns into fear when he sees his whole family gathered around the table, ready to toast to his brother's unexpected comeback with the doctored chicha. Amazingly enough, all guests empty their glasses at one gulp and declare to be delighted by the outstanding taste. Totally puzzled, the protagonist, treats the invitees to the original wine, presenting it as another excellent drink he just bought, but all of them are disgusted by its only smell. His father bashes and blames him for being trapped by an insolent swindler, before throwing the cask onto the street, where a car runs it over and a dog pees on it (1994: 109). Once more, humor is derived from the incongruity included in the contradictory ending generated by the inexplicable transformation of the liquid. ${ }^{10}$

In a nutshell, the common denominator is that in all stories treated humor pops up as a mere consequence of the surprising clash of an uncanny element and the referential framework of daily life. More specifically, the existence of a double, the magic of the pin, and the mysterious alteration of the chicha cause an incongruity with the reader's expectations and install a «comic key or tone» which, according to Vandaele «can be defined as lightheartedness (as opposed to gravity) that authors and author-like narrators suggest as the right attitude toward a work or parts of it - even when they accomplish this via an exaggeratedly serious one (so that the lightheartedness is in the exaggeration)» (2010: 777-778). This way, in these samples of the 'fantastic of perception', humor comes across as an epiphenomenon that cheers up the oppressive and threatening sensation given by the fantastic. As a consequence, it is essentially a «physical» or «situational humor» (Ermida, 2008: 41) and it does not play a part in the narrative structure of the fantastic as such.

\section{The 'Fantastic of LANGUAgE': HUMOR as A CAUSE}

On the contrary, when the 'fantastic of language' puts forward humor, it appears as an aspect inherent in narrative organization itself and corresponds to what Vandaele labels as «narrative humor». In this type of humor

10 In this case, incongruity is also prepared by what Vandaele defines as a «comic narrative suspense», a process through which «spectators may understand» the hero's frustration but «will not easily identify with his incongruous/ inferior plans and implementation. The suspense related to him is therefore experienced in a detached, comic manner» (2010: 746). 
«audiences/ readers encounter narrative participants («agents») in different humorous roles. Explaining narrative humor is showing how narrative enables its participants to produce humor, that is, incongruity and superiority» (2010: 781). Effectively, humor seems to be intrinsically related to the parameters of narratology that, according to Genette, are the most decisive for the presentation of narrative: focalization and narration (1972: 76). In order to illustrate this relationship, we will first demonstrate how humor ensues from a defective narration caused by a selective enunciation in Escena de caza and by a circular, self-destroying composition in El carrusel. Secondly, we will study how the subtle play with the character's points of view in Sobre las olas and Scorpio leads to focalizations that are so suggestive that they tend to mislead the reader and generate both a humorous and a fantastic effect. ${ }^{11}$

\subsection{Defective narration}

In Escena de caza, a story that displays a ludic-fantastic mode combining the transgression of common sense with the oscillation between the real and the unreal (Rodero, 2000: 89) so that it is almost as emblematic as Doblaje (2000: 90), humor is rooted in the absurd events and, most of all, in the tricky way these events are told. The narrator and his cousin Ronald want to teach their sons Harold and Ramón to hunt pigeons. With this in mind, they head for Sayán, in the Lima countryside, where they should arrive at daybreak, before the birds fly out in search of food. However, due to some loitering and repeated setbacks - the children oblige them to stop every other minute, they burst a tire and, to top it all, get lost - they only get to the spot when the sun is burning and there is no trace yet of the most miserable sparrow: «no se veía ni el más mínimo gorrión» (1994: 625). Despite this, the kids refuse to give up, but in a whole day they only shoot a few small birds, until Ronald decides to have a last try at dusk, near a pigeon-nest disclosed to him by his late father, George. Inspired by this fabulous hunter, who functions as a reference point for the characters' actions -the narrator imagines how «tío George» would laugh at their poor catch; repeats constantly that he was a crack-shoot; and reminisces about the time that Sayán belonged to George's family's hacienda (1994: 626-627)-, Ronald disappears in the twilight. Suddenly the other hunters see some twenty

11 These four tales belong to three different collections: Escena de caza is incorporated in Solo para fumadores (1987), Sobre las olas and El carrusel are both integrated in Silvio en El Rosedal (1977) and Scorpio is part of Cuentos de circunstancias (1958). 
doves falling, while only one shot was fired, and a voice that cannot be located forbids them to pick up the animals so that one more volley can slaughter another «rain of pigeons», «una nueva lluvia de palomas» (1994: 629). Nevertheless, more than the disproportion between the number of salvos and the shot birds or the darkness which makes aiming impossible, it is mainly the gap in narration that reveals the incongruity, as can be inferred from the conversation between the protagonist and Ronald after the latter has popped up again:

Nuestro honor quedó a salvo. ¿No te parece? Ha sido una buena batida.

-Gracias a ti —dije.

— ¡Vamos, vamos, déjate de cumplidos! Tú sabes bien que ni tú ni yo hemos disparado un solo tiro.

— ¿No? ¿Entonces quién?

- La quinta sombra... la que se desprendió de mí o la que sigue apostada allí, sin que pueda moverse nunca, en el dormidero (Ribeyro, 1994: 630).

Effectively, narration seems to be overtaken by the events: while the narrator's discourse attributes the marvelous round-up to the shooter's ability, Ronald denies it by stating that there was no shot at all — «ni tú ni yo hemos disparado un solo tiro»— and invoking the enigmatic presence of a fifth person, «la quinta sombra». That shadow, which obviously was posted at the dove's sleeping-place, might have broken free out of Ronald and be superposed on the spirit of his father George, whose gestures and behavior he increasingly adopts: «lo vi vacilar y tirarse los pelos de una ceja, como tantos años atrás había visto hacer al tío George» (1994: 628). Hiding these events for a while and revealing them only at the end in the testimony of the eccentric Ronald, the narration actually emphasizes incongruity, which ridicules the atmosphere of resignation the reader was prepared for and entails a fantastic ending.

Such a defective narration is also installed in El carrusel, where, in addition, it is related to an aberrant time structure. While the changing of narrators in traditional story-telling is only assured by a delegation from the extradiegetic to the intradiegetic level or, at that same intradiegetic stage, between characters engaged in conversation, the narration in this tale consists of an unlikely relay of fifteen intradiegetic narrators that all act as if they were extradiegetic. That sort of chain reaction sets off with the I-narrator's arrival (1) at Frankfort, where he meets an invalid Second World War veteran with a mechanic hand (2), who tells him he used to store cheeses in his boardinghouse, upon which his landlady (3) suggests he should lay in canned food, just like her uncle Nicolás did when he had been shipwrecked on an island. On that island, a Frenchman 
(4) had told her uncle and his friend about the experiences of a Senegalese man (5), who had seen a woman named Monique crying because of what had happened to her brother. The brother (6) reports how he had wanted to make love to a certain Socorro in a hotel room, when a plumber (7) came out of the bathroom testifying he only had seen comparable damage at miss Nguyen's place. This Vietnamese lady (8) relates that, during the war in her country, she was about to set off for France when a bomb explosion hurt an American sergeant (9), who witnessed how a quarrel between three of his compatriots and a waiter about some ordered drinks was patched up by the barkeeper (10), just as one captain Dupuis had done before him. Dupuis (11) dwells on French rationalism until he is interrupted by an insolent Moroccan student, an impertinence for which the latter has to appear before the headmaster (12), who quotes one of general Ney's discourses reproduced on a leaflet that, according to the headmaster's daughter (13), was stolen by her brother's friend, Pibe Lanusse. Lanusse (14) elaborates on the many different ways a man can die, going more deeply into the destiny of the butler Pilic, who had been hit by shrapnel, which reminded the doctor that was treating him (15) of the adventures told by a guy who arrived in Frankfort and had his nose and ears pinched off by a man with a mechanic hand, a discourse that identically repeats the first lines of the story:

-El primer día que llegué a Francfort tomé un hotel cerca de la estación del ferrocarril, dejé mi equipaje y salí a dar una vuelta, sin plano ni plan preciso. Nada es más agradable que recorrer un poco a la aventura una ciudad que no conocemos, sin saber cuáles son sus calles céntricas, sus monumentos, sus costumbres. Todo para nosotros es una sorpresa... (Ribeyro, 1994: 542).

It is quite apparent that the incongruity does not essentially result from the plot but rather from the haphazard succession of narrators: if some of the stories might be funny or absurd on their own, this comic impression is mainly generated by their unachieved aspect caused by a narration that runs wild. This unstoppable mechanism which generates a comic effect on its own ${ }^{12}$ mainly parodies common mimetic and realistic mechanisms of narrative (Rodero, 2000: 87) and gives birth to a metanarrative humor that finally leads to the fantastic. As Rodero states, the transgression that through the ludic-fantastic mode affected the narrated world, the «transgresión/ desrealización del mundo narrado», is now extended to narrative structure as such (2000: 86). Creating a cascade of

12 According to Bergson, such a mechanical chain of events is an undeniable characteristic of the comic: «Est comique tout arrangement d'actes et d'événements qui nous donne, insérée l'une dans l'autre, l'illusion de la vie et la sensation nette d'un agencement mécanique» (1991: 53). 
discourses and short-circuiting narration in according with its title, the tale evolves towards a hilarious 'mise en abyme' that endangers its own existence and subsequently activates the reader's vacillation (2000: 88).

This smooth evolution from a humorous to a fantastic effect is strengthened by a spatial indetermination - in the quoted fragment, Frankfort is presented as an ideal décor for such a process since it allows the narrator to go on random walks through the city without «maps or plans» and comes across, much like the weird narration, as a constant surprise - and by the incoherence in chronology as well. Embedding miss Nguyen's and the American sergeant's testimonies during the Vietnam conflict into the aftermath of the Second World War, which constitutes the global time frame of El carrusel and has to be situated some twenty years before, the narration breaks the logical temporal succession and installs the impossible into the narrated world (Rodero, 2000: 89). ${ }^{13}$ This way, the aberrant time structure also installs a kind of humor Vandaele qualifies as «metanarrative, because it is a comic comment on the rules and expectations of narration, just as wordplay is a metalinguistic phenomenon, because it highlights features of language that are usually expected to be backgrounded in language use» (2010: 738) and contributes to the 'fantastic of language'.

\subsection{Suggestive focalization}

In Sobre las olas it is the protagonist's dominant perspective that gradually builds up the incongruity and ensures the surprising dénouement of the story contains both a humorous and a fantastic effect. The autodiegetic narrator remembers how he strolled along the San Miguel boardwalk in Lima with his uncle Fermín in order to get rid of the image of his grandmother, who at that same moment was dying of a brucellosis attack. At the beach he sees an experienced swimmer getting in trouble, a scene that comes across as very alarming because of the inexplicable change of weather —while San Miguel normally has a climate that anyone is proud of (1994: 503) and the forecasts looked excellent,

13 This ludic aspect is also reinforced in some character's discourses that repeat certain words as a kind of inner rime — like «conservas» / «conservan» or «sustraído»/ «sustracción»— and create a similar impression of circularity in the following examples: «ipor qué no compra más bien conservas que son, por definición, bienes que se conservan» (Ribeyro, 1994: 537) or «se ha sustraído un documento que condena la sustracción» (1994: 541). Furthermore, this story also integrates some impossible aspect that is typical of the fantastic of perception, like the two shipwrecked sailors who, in order to get themselves some food parcels, swim every day in a perfect butterfly style the several miles that separate the island from the ship that ran ashore (1994: 537). 
the sportsman who swims back and forth «en un estilo perfecto» is overtaken by a «fuerte brisa» and caught into a treacherous sea (1994: 503-504) — and because of the 'Homeric' comments of Fermín, who takes pleasure in impressing his nephew with references to the Iliad and relates the swelling waves to the whims of Neptune (1994: 504). Together with the other passers-by, the hero witnesses how, against all odds, the skillful man -aware of the danger, he avoids the waves and returns to calmer water, some people go for a life buoy but the breakers throw it back onto the shore and, when finally they send for a life boat, the rescue team cannot locate the victim- eventually drowns, in an ironic way, at the very moment the waters are flat again like «una taza de agua» (1994: 506). This disturbing scene is meticulously reproduced through the eyes of the protagonist: while his uncle had to return home to check some worrying news about the terminally ill grandmother, he observes how the drowning person shrinks to a «punto negro» (1994: 505) progressively swallowed by the waves:

desde mi nueva posición lo distinguí, cada vez más lejos de nosotros. (...) Vimos el pequeño punto negro que derivaba tras los tumbos, sin sacar los brazos ya, desapareciendo por momentos. (...) se multiplicaron los gritos (...). Pero esos gritos se dirigían a un ser fantasmal. (...) Cada cual quería ver a su propio ahogado. Yo vi el mío, un punto indeciso y hasta unos brazos que en lugar de avanzar hacia la costa se internaban desesperados hacia altamar. (...) Yo creía ver un último punto, que reaparecía por donde nadie lo buscaba y en vano seguí mirando pues nada volví a ver (Ribeyro, 1994: 506).

Actually, the protagonist's focalization prepares a contrast with the grandmother's situation, which simultaneously generates humor and the fantastic at the end of the tale. Getting the swimmer gradually out of focus - the black spot becomes smaller and smaller until it turns into something ghostly, «fantasmal», or even into nothing at all, like he supposes his grandmother is doing at that same moment - the hero becomes a sort of guardian angel whose intensive perception redeems with the swimmers life the fate of his grandmother. In her bedroom, the smell of hospital and mortuary — «olía a éter, timolina, hospital, cámara mortuaria» (1994: 507)— suddenly vanishes when she sits up, alive and kicking and ready to shake the hero's hands as if she soared out of the top of a wave: «distinguí a mi abuela, pero no exangüe y rígida, sino (...) sonrosada y sonriente, extendiendo ambos brazos hacia nosotros, como si emergiera triunfal en la cresta de una ola» (1994: 507). ${ }^{14}$

14 A quite similar contrast between the character's focalization and the dominating perspective can be found in El marqués y los gavilanes (Silvio en El Rosedal, 1977), where the protagonist, the marquis Diego 
While in the former text the incongruity, which peaked in the unexpected ending, was prepared by the hero's global focal activity and interpretations, in Scorpio, another classic example of Ribeyro's fantastic creation (Honores, 2010: p. 236), it proceeds from the very lexical elements that are integrated in the main character's focalizations (Snauwaert, 2016: 1083-1084). ${ }^{15}$ In this tale, Ramón behaves as if he were «endemoniado» (Ribeyro, 1994: 122), possessed by the devil, when he remembers how he has been overpowered by his elder brother Tobías. In their garden, Tobias appropriated a scorpion that Ramón, a great insect and arthropod-lover, had seen first and took it to his sleeping room to lock it up under a bell-glass and torture it. At night, while watching the constellation of Scorpio, Ramón feels a growing pity for the maltreated scorpion and the moon, which seems to consist of a slow movement of shadows as if it contained a mass of worms — «le pareció que en el interior de la luna se efectuaban lentos desplazamientos de sombras, como si contuviera una masa de gusanos» (1994: 124)—, inspires him to take revenge. Like an experienced burglar he creeps into the room of his sleeping brother and releases the poisonous animal between his blankets. This punishment would not have had anything to do with humor nor with the fantastic, if we had not taken into account that the protagonist focalizes the attack assimilating the viewpoint of the scorpion itself:

Como hacía calor, [Tobías] dormía cubierto por la sábana, sobre la cual sus dos manos yacían inmóviles, como dos arañas de mar. «Scorpio luchará contra las arañas», pensó [Ramón], y con el cartón en la mano fue aproximándose al lecho. Se detuvo un momento, respirando agitadamente y, levantando la campana, dejó resbalar al animal. Al cruzar bajo los manzanos, de regreso al jardín, recordó al escorpión, recortado sobre la sábana blanca, avanzando cautelosamente, con el aguijón erguido hacia el dominio de las arañas (Ribeyro, 1994: 126).

The adoption in Ramón's perspective of the scorpion's favorite food, a nutrition process of which he knows all the details — «Yo le daría a comer moscas, arañitas, lo trataría como un rey» (1994: 122) — and that was announced by the worms he imagined crawling in the moon close to Scorpio,

Santos de Molina, fears that his aristocratic privileges will be abolished by the reform-minded family Gavilán y Aliaga. This threat makes the hero suffer to the extent that he imagines he is being attacked by a huge sparrow hawk, the bird alluded to in the name "Gavilán» (Ribeyro, 1994: 480), which causes a humoristic effect. However, since that focalization can also be interpreted in a psychological way, as a mere hallucination caused by the protagonist's paranoia, instead of exclusively as an uncommon aspect that invades reality, its fantastic implication is not as clear as that in the example discussed above.

15 More specifically, these lexical elements refer to the idiolect or to some interest typical of a character. When integrated into the narrator's discourse, they indicate that focalization is delegated to the corresponding character, whose viewpoint subsequently determines the scope of the story (Snauwaert, 2014: 52). 
generates an incongruent point of view that makes the reader smile. At the same time, this incongruity also increases the suspense: we do not know whether the animal will sting Tobías or not: we only see it ready to hit and heading for the bait that are the boy's spider-like immobile hands. At this stage, the insinuating perspective stimulates vacillation and, in doing so, goes hand in hand with the fantastic stamp the scorpion sets on the whole tale. The appearance of the arthropod that resembles a sophisticated machine made out of copper plates and oiled articulation — «lo que admiraba era su estructura metálica (...) Parecía construido con planchas de cobre y aceitado en sus articulaciones» (1994: 125) — also fits in with the global atmosphere of the garden from where Ramón observes Scorpio, the constellation that is included in the title and overarches the story: the jasmines shine like stars — «estrellas en el cielo»- against the ivy and the moonshine that falls on the apple trees turns them into something artificial and metallic, «les imprimía un aspecto artificial y metálico» (1994: 123). In brief, the scorpion should be interpreted as an unequivocal instrument of the fantastic, not because of its frightful appearance, but because it impregnates the whole setting, triggering both humor and vacillation through the hero's perspective. ${ }^{16}$

In both short stories humor is part of the narrative structure itself: the shifts in focalization filter the events through the viewpoints of the characters, and thereby, create incongruity. Similar to the examples of defective narration, the humor conveyed by an incongruent perspective becomes an essential tool of the 'fantastic of language'. As a result, humor has to be considered not as a simple consequence of the fantastic, but as a preceding or concurrent mechanism which on its own is able to generate vacillation, the founding concept of the genre. In Sobre las olas, the hero's viewpoint progressively announces the incongruous ending, which comes across both as humorous and fantastic, and in Scorpio the association of Ramón's perspective to the scorpion's perception results in a disproportional comical focus which creates suspense and immerses the whole story in an ethereal atmosphere. In other words, by the manipulation of narration and focalization they display, these tales are not funny «because of what» they represent, but because of «how» they represent (Vandaele, 2011: 182), ${ }^{17}$ which definitely

16 Even though it is not as clear as in the commented example, a comparable effect can be traced in $D e$ color modesto (Las botellas y los hombres, 1964), where the contrast between the protagonist's fascination for a woman of a lower class and the narrator's scornful comments generates humor and allows the reader to interpret the unusual relationship in a fantastic way (Snauwaert, 2016: 1089-1091).

17 Vandaele also formulates that difference from a discursive viewpoint in De Saussure's well-known terms, stating that such a narrative humor does not proceed from «language» but from «parole» (2012: 86). 
puts forward narrative humor as one of the enunciation strategies that are typical of 'the fantastic of language'.

\section{CONCLUSIONS}

The analysis of Julio Ramón Ribeyro's humorous fantastic stories has shown us that the relationship between the fantastic and humor is essentially determined by the modality by which the former takes shape. In 'the fantastic of perception' humor is derived from the incongruity that is established by the collision between an uncommon aspect and the mundane setting of everyday life. Therefore, it comes across as posterior, situational, more superficial or, in other words, as a mere consequence that may follow on the fantastic. On the other hand, in 'the fantastic of language', humor is an integrating part of the narrative process, where it operates simultaneously or even previously to the fantastic and, in this respect, can be seen as one of its causes.

As far as this last modality is concerned, the manipulation of enunciation that takes place in a defective narrative, which presents itself as deceiving by erasing vital information or entails self-destruction by using a confusing circular setup, results in a clash with general expectations, which is experienced by characters and readers as both humorous and disquieting at the same time. That vacillation, which is indispensable for the genre, is also stimulated by the incongruous and humorous effect caused by the focal activity of some protagonists that filter the narrators discourse in a suggestive way preparing a disturbing ending or establishing an uncommon viewpoint. Profiling itself as a tool that helps configure the fantastic, humor participates in the technical mechanism of the 'fantastic of language', and subsequently has to be considered as a relevant avenue in the study of contemporary fantastic literature as such.

BiBLIOGRAPHY

AlARCóN, Víctor (2013): «De la risa a la inquietud. El humor en la literatura fantástica», in David Roas and Patricia García (eds.), Visiones de lo fantástico (aproximaciones teóricas), e.d.a., Málaga, pp. 72-87.

Alber, Jan (2011): «The Diachronic Development of Unnaturalness: A New View on Genre», in Jan Alber, Rüdiger Heinze (eds.), Unnatural Narratives-Unnatural Narratology, De Gruyter, Berlin/ Boston, pp. 41-67.

— and Monika FLUDERNIK (2010): «Introduction», in Jan Alber and Monika Fludernik 
(eds.), Postclassical Narratology. Approaches and Analyses, Ohio State University Press, Columbus, pp. 1-31.

Antonopoulou, Eleni (2002): «A Cognitive Approach to Literary Humour Devices: Translating Raymond Chandler», The Translator, 8:2, pp. 195-220. DOI: 10.1080/13556509.2002.10799132

Attardo, Salvatore (2001): Humorous Texts: A Semantic and Pragmatic Analysis, Mouton De Gruyter, Berlin/ New York.

Bergson, Henri (1991) [1940]: Le rire. Essai sur la signification du comique, Presses Universitaires de France, Paris.

ChAnAdy, Amaryll Béatrice (1985): Magical Realism and the Fantastic. Resolved versus Unresolved Antinomy, Garland Publishing, New York/London.

ERDAL JoRdan, Mery (1998): La narrativa fantástica. Evolución del género y su relación con las concepciones del lenguaje, Vervuert/Iberoamericana, Frankfurt/ Madrid.

Ermida, Isabel (2008): The Language of Comic Narratives, Mouton De Gruyter, Berlin/ New York.

Genette, Gérard (1972): Figures III, Seuil, Paris.

HonOres, Elton (2010): Mundos imposibles. Lo fantástico en la narrativa peruana, Cuerpo de la Metáfora, Lima.

- (2011): «Ortodoxos y heterodoxos: hacia un panorama de la narrativa fantástica peruana contemporánea (1980-2010) desde el sistema literario», in Elton Honores (ed.), Lo fantástico en Hispanoamérica, Cuerpo de la Metáfora, Lima, pp. 11-37.

Hutcheon, Linda (1995): Irony's Edge. The Theory and Politics of Irony, Routledge, New York.

Ortega, Julio (1985): «Los cuentos de Julio Ramón Ribeyro», Cuadernos Hispanoamericanos, 417 , pp. 128-145.

Rabatel, Alain (2009): «A Brief Introduction to an Enunciative Approach to Point of View», in Peter Hühn, Wolf Schmid and Jörg Schönert (eds.), Point of View, Perspective and Focalization, De Gruyter, Berlin, pp. 79-98

RAsKIN, Victor (1985): Semantic Mechanisms of Humor, D. Reidel, Dordrecht/ Boston/ Lancaster.

RibeYro, Julio Ramón (1994): Cuentos completos, Alfaguara, Madrid.

RoAs, David (2011): «Más allá de los límites del lenguaje. Lo fantástico como subversión discursiva», in Elton Honores (ed.), Lo fantástico en Hispanoamérica, Cuerpo de la Metáfora, Lima, pp. 263-272.

— (2012): «Cronologías alteradas. La perversión fantástica del tiempo», in Flavio García and Maria Cristina Batalha (eds.), Vertentes teóricas y ficcionais do Insólito, Editora Caetés, Rio de Janeiro, pp. 106-113.

Rodero, Jesús (2000): «Del juego y lo fantástico en algunos relatos de Julio Ramón Ribeyro», Revista Iberoamericana, LXVI.190, pp. 73-91.

Rodríguez HERnÁNDEZ, Tahiche (2010): «La conspiración fantástica: una aproximación lingüístico-cognitiva a la evolución del género», Espéculo. Revista de estudios literarios, 43, pp. 1-11. http: / / www.ucm.es/info/ especulo/ numero43consfan.html.

SNAUWAERT, Erwin (2014): «Hacia una traducción adecuada de la focalización», Dialogía. Revista de lingüística, literatura y cultura, 8, pp. 44-70.

https: / / www.journals.uio.no/index.php/Dialogia/issue/viewIssue / 107 / 14 
- (2016): «Lo fantástico y el humor: paralelismos en el funcionamiento e implicaciones para la traducción». (Re)Visões do Fantástico: do centro às margens; caminhos cruzados, in Flavio García, María Cristina Batalha and Regina Silva Michelli (eds.), Dialogarts Publicações, Rio de Janeiro, pp. 1081-1094.

Todorov, Tzvetan (1970): Introduction à la littérature fantastique, Seuil, Paris.

VAndaele, Jeroen (2010): «Narrative Humor (I): Enter Perspective», Poetics Today, 31:4, pp. 721-785.

— (2011): «Wordplay in translation», in Yves Gambier and Luc Van Doorslaer (eds.), Handbook of Translation Studies, John Benjamins, Amsterdam, pp. 180-183.

— (2012): «Narrative Humor (II): Exit Perspective», Poetics Today, 33:1, pp. 59-126.

VIDAL, Luis Fernando (1975): «Ribeyro y los espejos repetidos», Revista de Crítica Literaria Latinoamericana, 1:1, pp. 73-87.

Weitzdörfer, Ewald (2008): «Lo fantástico en los cuentos de Julio R. Ribeyro», Alpha, 26, pp. 193-202. 